\title{
ANALISIS ANTRIAN PADA LOKET PEMBUATAN ELEKTRONIK KTP DENGAN MENGGUNAKAN SIMULASI PROMODEL
}

\author{
Riri Cornellia \\ Teknik Industri, Universitas Indraprasta PGRI \\ ajmasierra88@gmail.com
}

\begin{abstract}
Abstrak
E-KTP atau KTP Elektronik adalah dokumen kependudukan yang memuat sistem keamanan/pengendalian baik dari sisi administrasi ataupun teknologi informasi dengan berbasis pada database kependudukan Nasional. Kelurahan merupakan salah satu tempat yang didatangi penduduk untuk membuat E-KTP tersebut. Namun tingginya antusiasme penduduk untuk memperbarui KTP maka muncullah permasalahan. Permasalahan yang terjadi ialah terjadi antrian yang panjang di beberapa daerah. Kurangnya sosialisasi informasi antara petugas dan penduduk serta penjadwalan sistematis kepada masyarakat sehingga mengakibatkan pelayanan menjadi kurang efektif. Hasil penelitian data dan analisis yang sudah dilakukan dengan menggunakan promodel Student Version 6.0 diperoleh bahwa pola kedatangan penduduk berdistribusi poisson sedangkan waktu pelayanan berdistribusi eksponensial.Output simulasi model tingkat utilitas dari fasilitas pelayanan dengan persentase rata-rata utilitas teller adalah sebesar $62.55 \%$ dan rata-rata waktu tunggu selama 12,71 menit perorang. Oleh karena itu dapat disimpulkan bahwa sistem antrian yang cukup lama dan utilitas rendah pada Kelurahan tersebut membuat pelayanan yang didapat penduduk menjadi tidak optimal. Seharusnya dengan menambah loket antrian, penjadwalan yang sistematis, dan fasilitas pendukung seperti penyuluhan layanan terbaru bisa dapat membantu mengatasi lamanya penduduk mengantri. Sehingga usulan atas perbaikan sistem tersebut sangat diperuntukkan bagi Kelurahan Kebon Pala, dalam rangka meningkatkan kualitas pelayanan yang lebih memadai supaya penduduk merasa puas terhadap fasilitas pelayanan yang diberikan dan dapat meminimalisir waktu mengantri.
\end{abstract}

Kata kunci :Sistem Antrian, Model Simulasi,Promodel

\begin{abstract}
E-KTP or Electronic KTP is a population document that contains a system of security / control both in terms of administration or information technology based on the National population database. Kelurahan is one of the places visited by residents to make the E-KTP. But the high enthusiasm of the population to renew their KTPs, problems arose. The problem that occurs is a long queue occurs in several regions. Lack of information dissemination between officers and residents and systematic scheduling to the community resulting in services being less effective. The results of the data and analysis studies that have been carried out using Student Version 6.0 can be found that the pattern of population arrivals is Poisson distribution while the service time is exponentially distributed. The simulation output of utility level models from service facilities with the average percentage of teller utilities is $62.55 \%$ and the average waiting time of 12.71 minutes per person. Therefore it can be concluded that the queuing system that is long enough and the utility is low in the Kelurahan makes the services obtained by the population not optimal. Supposedly by increasing the queue window, systematic scheduling, and supporting facilities such as counseling the latest services can help overcome the duration of the population queuing. So that the proposal for the improvement of the system is very intended for Kebon Pala Village, in order to improve the quality of services that are more adequate so that residents feel satisfied with the service facilities provided and can minimize the time in line.
\end{abstract}

Keywords: Queue System, Simulation Model, Promodel

\section{PENDAHULUAN}

Salah satu program pemerintah yang sedang digalakkan sekarang ini ialah pembuatan Kartu Tanda Penduduk Elektronik (e-KTP). Setiap warga negara Indonesia diwajibkan untuk 
membuat/mengganti KTP lama menjadi KTP Elektronik. Pembuatan Elektronik Kartu Tanda Penduduk (e-KTP) Tahun 2016 mengalami lonjakan antrian di beberapa daerah. Kurangnya sosialisasi informasi antara petugas dan penduduk serta penjadwalan sistematis kepada masyarakat sehingga mengakibatkan antrian yang panjang dalam pembuatan eKTP di setiap kelurahan. Tujuan dari penelitian yang diperoleh yaitu menerapkan simulasi loket antrian apakah sudah optimal atau belum. Untuk mengetahui banyakanya penduduk yang dapat dilayani selama 8 jalam kerja dengan menggunakan promodel.

Manfaat dari penelitian ini yaitu mendapatkan penegtahuan mengenai sistem antrian yang ada pada pelayanan Kelurahan, mengetahui tingkat utilisasi dan memperoleh hasil analisa sebagai acuan perbaikan sistem ke depan. Kedatangan merupakan karakteristik populasi yang akan dilayani (colling population) dapat dilihat menurut ukurannya[3]. Pelayanan mekanisme dapat terdiri dari suatu atau lebih pelayanan, atau satu atau lebih fasilitas pelayanan. Tiap pelayanan kadang-kadang disebut sebagai saluran (channel) [4]. Ada 3 aspek mekanisme pelayanan [4] yaitu : tersedianya pelayanan, lamanya pelayanan dan kapasitas pelayanan.

Antrian adalah suatu keadaan sistem pelayanan dimana kedatngan waktu pelanggan lebih besar daripada waktu pelapayan. Contoh sederhana suatu antrian adalah proses pembayaran pajak kendaraan bermotor dimana waktu kedatangan pelanggan lebih besar dari pada waktu pelayanan petugas yang sedang melayani pembayaran sehingga menyebabkan antrian [5].

Sistem adalah sekumpulan elemen- elemen yang bekerja sama untuk mencapai tujuan yang diinginkan. Dari definisi tersebut dapat ditarik beberapa kesimpulan yaitu sistem terdiri dari beberapa elemen yang saling berhubungan dan berinteraksi [1]. Model adalah representasi dari sistem nyata yang disederhanakan. model merupakan alat yang sangat berguna untuk menganalisis maupun merancang sistem [2]. Dengan membuat model dari suatu sistem maka diharapkan dapat lebih mudah untuk melakukan analisis [1].

Simulasi adalah imitasi dari suatu sistem dinamis menggunakan model komputer untuk mengevaluasi dan meningkatkan performansi sistem [1]. Kelebihan dari penggunaan simulasi adalah menghindari penggunaan biaya yang mahal, tidak memakan waktu lama dan tidak menggnggu sistem yang berjalan.

Menurut survei penelitian, pihak Kelurahan Kebon Pala memprediksi sanggup menyelesaikan entri data warga dalam satu hari adalah 150 orang dengan pelayanan maksimal berkisar 2-3 menit setiap orangnya. Namun kenyataan yang terjadi pada saat observasi berlangsung, tidak sesuai dengan prediksi. Banyak warga yang datang berbondong-bondong menuju kelurahan, berharap dilayani lebih awal, tetapi malah sebaliknya antrian sangat panjang yang tidak dapat dihindari. Hal ini menyebabkan kurangnya optimalisasi atas kelancaran pembuatan eKTP tersebut, dikarenakan kapasitas pelayanan melebihi kapasitas pelayanan yang ada. Masalah ini menimbulkan ketidaknyamanan penduduk karena harus menghabiskan waktu yang cukup lama untuk mengantri. Antrian yang terlalu panjang biasanya akan dilakukan pembatalan/penutupan pendaftaran sepihak. Oleh karena itu waktu merupakan sumber daya yang sangat diperhitungkan, maka efisiensi dalam pelayanan pada waktu-waktu tertentu merupakan topik menarik untuk dianalisis. Melihat permasalahan antrian seperti yang terjadi dalam pembuatan e-KTP tersebut, maka 
salah satu teknik untuk memecahkan masalah ini bisa menggunakan metode simulasi. Promodel adalah sebuah software simulasi berbasi windows yang digunakan untuk mensimulasikan dan menganalisis suatu sistem [5]. Simulasi Promodel 6.0 adalah alat yang memfasilisator dalam menganalisis untuk merancang model sistem yang secara akurat merepresentasikan secara jelas sistem yang dimuat.

\section{METODE PENELITIAN}

\section{Waktu dan Tempat Penelitian}

Penelitian dilakukan dikantor Kelurahan Kebon Pala Makassar yang terletak di Jl. Cipinang Asem no. 38 Jakarta Timur pada jam kerja Pk 08:00-13:00 selama 4 hari tanggal 11,12,13, dan 14 Februari 2016.

Metode penelitian yang digunakan dalam pengumpulan data dengan cara observasi dan dokumentasi. Penggunaan metode berdasarkan kebutuhan untuk data, pengambilan data secara langsung ketempat penelitian sesuai data yang dibutuhkan.Setelah mengidentifikasi masalah yang ada, maka selanjutnya peneliti melakukan studi pustaka untuk memecahkan masalah yang ada yaitu dengan mencari metode yang sesuai untuk melakukan pengolahan data. Studi pustaka ini dapat berupa teori-teori dari berbagai sumber yang berhubungan dengan masalah yang ada dan selanjutnya kita dapat menentukan tujuan penelitian kita berdasarkan studi pustaka.

Untuk memperoleh data dalam penyusunan, peneliti menggunakan beberapa teknik pengumpulan data yaitu dengan cara penelitian lapangan ( meliputi wawancara dan observasi ) dan juga penelitian kepustakaan. Instrument penelitian digunakan berupa penelitian lapangan / pengamatan secara langsung untuk kedatangan penduduk dengan wawancara dan observasi. Peralatan yang digunakan berupa Alat tulis dan Stopwacth.

\section{Simulasi dengan Menggunakan Software Promodel 6.0}

Promodel merupakan salah satu software simulasi yang dapat berjalan di atas platform Windows untuk disimulasikan dan menganalisis sistem produksi dari seluruh tipe sistem dan ukuran. Promodel menyediakan kombinasi yang sempurna dari kemudahan, fleksibilitas.dan kemampuan untuk memodelkan semua situasi dan dengan kemampuan animasi yang hidup membuat simulasi semakin nyata.

Promodel menyediakan bagi para insinyur dan manajer kesempatan untuk mencoba ide baru untuk desain sistem atau perbaikan seblum menyediakan waktu dan bahan baku yang dibtuhkan untuk membuat atau merubah sistem aktual yang ada. Promodel memfokuskan pada persoalan seperti utilisasi sumber, kapasitas produksi, produktivitas dan inventori. Dengan memodelkan elemen penting dalam sistem produksi utilisasi sumber, kapasitas sistem, dan jadwal produksi maka eksperimen dapat dilakukan dengan operasi dan desain yang berbeda untuk memperoleh hasil yang terbaik[6].

Langkah-langkah yang harus dilakukan untuk memulai promodel adalah:

a. Pertama-tama kita buka program Promodel dengan cara mengklik menu Start kemudian All Program dan selanjutnya pilih Promodel

b. Selanjutnya untuk membuat model simulasi yang baru, pilih menu File, New kemudian akan tampil General Information Window. pada bagian Title diisi dengan judul model yang diinginkan. Pada bagian Time Unit dan Distance Unit diisi dengan satuan jarak dan waktu yang kita inginkan. Selanjutnya kita pilih Graphic Library yang akan kita gunakan 
sesuai dengan jenis simulasi yang akan kita buat bisa berupa industri, bank, logistik, dan lain-lain.

\section{Elemen-Elemen Promodel}

Untuk membuat model sebuah sistem, software Promodel 6.0 telah menyediakan beberapa elemen yang dapat membantu penyusunan model [7] Elemen-elemen dasar tersebut antara lain:

\section{a. Location}

Location mempresentasikan suatu tempat dimana entities diarahkan untuk suatu proses, penyimpanan atau aktivitas lain atau pengambilan keputusan. Untuk membuat suatu location mula-mula dengan masuk ke Build Menu lalu pilih Locations.setelah itu ProModel akan memunculkan window yang terdiri dari 3 window yaitu Location Grapihic Window, dan Location Edit Table.

Langkah-langkah untuk membuat lokasi baru yaitu :

1) Klik pada Checkbox New untuk membuat lokasi baru

2) Pilih grafik lokasi yang anda inginkan pada Location Graphic Window

3) Letakkan lokasi yang anda pilih pada layout window.

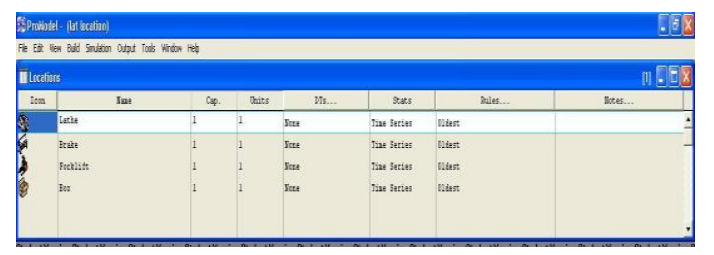

Gambar 2. Tampilan Window Edit location Sumber : Promodel Corporation 6.01.21:2003

Adapun atribut dari lokasi dapat kita ubah pada Location Table Window yang antara lain berisi:

1) Icon, merupakan grssafik yang mewakili lokasi yang bersangkutan

2) Name, merupakan nama dari lokasi. Namun harus dimulai dengan huruf dan maksimum panjang 80 karakter

3) Cap, adalah jumlah entities yang dapat diproses dalam satu unit waktu
4) Unit, merupakan banyaknya unit lokasi tersebut

5) Dts, merupakan pilihan untuk mensetting Down-times dari mesin dapat berupa berdasarkan wakt, banyak material yang masuk, ataupun lama pemakaian.

6) Stat, merupakan pilihan seberapa detail lokasi tersebut akan dicatat secara statistik pada saat simulasi dijalankan, time series merupakan pilihan paling detail

7) Rules, merupakan aturan bagaimana barang akan masuk, keluar dan diproses dilokasi tersebut apakah FIFO, LIFO, random dan sebagainya.

\section{b. Entities}

Entities adalah segala sesuatu yang diproses.Orang barang atau dokumen bisa didefinisikan sebagai entities. Langkah-langkah untuk membuat entities adalah sebagai berikut:

1) Setelah memilih Entities pada Menu Build maka akan muncul Entiy graphics dan menu edit untuk Entities. Pilih checkbox New untuk membuat entiti baru. Lalu pilih jenis entiti yang diinginkan.

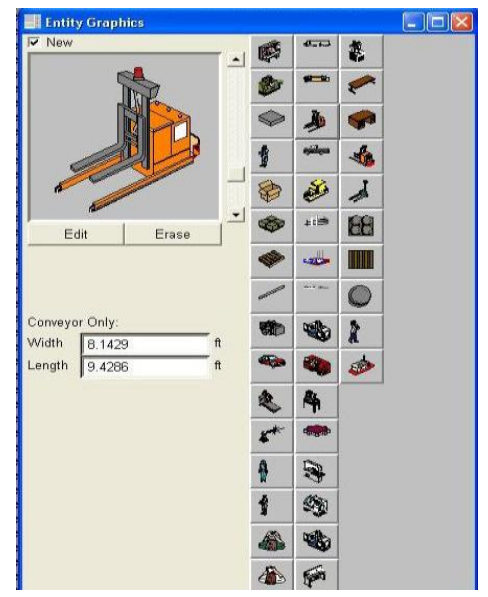

Gambar 3. Tampilan Entities

Sumber : Promodel Corporation 6.01.21:2003

2) Pengisian dapat dilakukan pada window edit entiti yang berisi antara lain: 


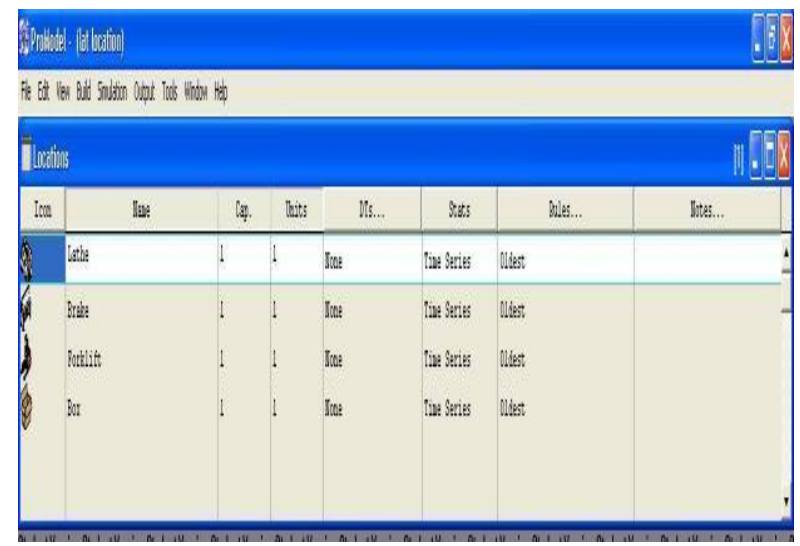

Gambar 4. Tampilan Window Edit Entities Sumber : Promodel Corporation 6.01.21:2003

a) Icon, merupakan petunjuk grafik yang mewakili entity yang bersangkutan pada saat simulasi dijalankan

b) Name, merupakan nama dari entity

c) Speed (Fpm), digunakan untuk menentukan kecepatan entity yang bergerak sendiri (bukan kecepatan entity akan diproses), dengan default $150 \mathrm{fpm}$

d) Stat, merupakan pilihan seberapa detail lokasi tersebut akan dicatat secara statistik pada saat simulasi dijalankan

e) Note, digunakan untuk menambahkan keterangan mengenai lokasi yang bersangkutan.

\section{c. Resources}

Adalah orang, perlengkapan atau suatu alat untuk melaksanakan satu atau lebih fungsi sebagai berikut :memindahkan entities, membantu melakukan perawatan pada suatu lokasi. Resources bisa dinamis, artinya berpindah-pindah atau statis, yaitu diam disuatu tempat. Langkah-langkah untuk membuat resources adalah sebagai berikut

1) Setelah memilih resources pada menu build maka akan muncul resources graphics dan menu edit untuk resources, Pilih checkbox New untuk membuat resources baru. lalu pilih jenis resources yang diinginkan.

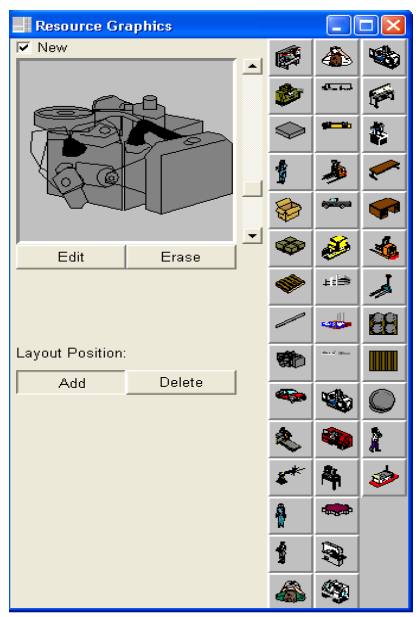

Gambar 5. Tampilan Resources Sumber : Promodel Corporation 6.01.21:2003

2) Pengisian dapat dilakukan pada menu edit resources yang berisi antara lain :

a) Icon, merupakan petunjuk grafik yang mewakili resources yang bersangkutan pada saat simulasi dijalankan.

b) Name, merupakan nama dari resources.

c) Units, jumlah unit yang dipresentasikan oleh resources.

d) Dts, berfungsi untuk menentukan downtimes

e) Stats, merupakan pilihan seberapa details resources tersebut akan dicatatsecara statistik pada saat simulasi dijalankan.

f) Specs, digunakan untuk menentukan path network, kecepatan resources, dll.

g) Search, digunakan untuk mendefiniskan pilihan searcwork dan park.

h) Logic, untuk mendifiniskan beberapa logic.

i) Notes, untuk memberikan catatan. 


\section{d. Processing}

Processing mendefinisikan rute dari entities dalam sistem dan operasi yang mengambil tempat lokasi yang dimasukinya. Langkahlangkah untuk membuat resources adalah sebagai berikut :

1) Setelah memilih Procesing pada menu Build maka akan muncul Process, Routing dan Tools Windows.

2) Klik New Process, lalu klik pada location dan arahkan pada location yang diinginkan. Dapat dilihat bahwa pada menu process akan terisi sendiri entities dan location. Untuk operation diisi sendiri sesuai operasi yang diinginkan.

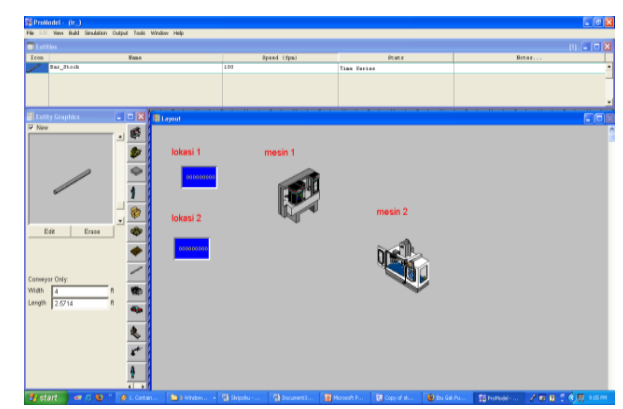

Gambar 6. Tampilan Processing

Sumber : Promodel Corporation 6.01.21:2003

Keterangan proses pada window process adalah:

1. Entity, menunjukan jenis entiti yang sedang kita buat prosesnya.

2. location, menunjukan lokasi tempat entity tersebut mengalami proses atau operasi.

3. operation, menunjukan operasi yang dialami, apakah perakitan, dikumpulkan, join, atau yang paling sederhana menunggu. Keterangan proses pada window routing adalah :

1. Output, menunjukan entiti yng keluar dari operasi tersebut.

2. Destination, menunjukan lokasi tujuan entiti yang berikutnya.

3. Rule, berisi aturan-ayuran rute.
4. Move logic, berisikan baris program untuk aturan perpindahan route entiti.

keterangan tambahan pada tools window :

1. Add Routing, digunakan untuk membuat rute berganda pada suatu proses.

2. Find Process, untuk mencari proses suatu jenis entiti pada location tertentu.

3. Route to Exit, digunakan bila proses telah berakhir dan suatu entiti menempuh rute keluar dari sistem.

4. View Routing, untuk melihat proses yang ditunjuk pada layout, sangat berguna pada layout yang sangat besar sehingga tidak semua location dapat dilihat sekaligus.

5. Snap lines to Border, untuk membuat garis rute cendrung lebih diarahkan pada area lokasi.

6. Show only Current Entity Routes, untuk mengaktifkan rute yang melibatkan entiti yang dipilih saja.

\section{e. Arrival}

Setiap entities baru yang masuk kedalam sistem dinamakan arrival. Catatan kedatangan didefinisikan dengan menspesifikasikan informasi sebagai berikut :

1. Jumlah entiti baru kedatangan

2. Frekuensi kedatangan

3. lokasi kedatangan

4. Waktu pertama kedatangan

5. Total kejadian kedatangan

Langkah-langkah untuk membuat arrival adalah sebagai berikut: Setelah memilih Arrival pada Menu Bild maka akan muncul Arrival dan Tools [8]. Lalu pada pengisian window edit arrival.

Adapun yang akan diisi pada tabel edit arrival adalah sebagai berikut: 
1. Entity, merupakan nama atau jenis entity yang akan diatur kedatangannya, dapat juga dipilih diantara entity yang telah kita buat pada window tools pada bagian kiri layout.

2. Locations, menunjukan pada lokasi mana entity tersebut akan memasuki sistem.

3. Qty each, menunjukan banyakanya entity yang tiba pada setiap kedatangan .

4. First time, menunjukan waktu pada saat entitiy pertama kali dimasukan sistem.

5. Occurrrences, merupakan junlah kedatangan entity selama $1 \mathrm{kali}$ simulasi dijalankan.

6. Frequency, merupakan waktu antar kedatangan.

7. Logic, merupakan tempat menambah logika pemrograman untuk mengatur kedatangan entity dengan lebih detail.

8. Disable, pilihan Yes atau No, digunakan jika kita ingin untuk menonaktifkan kedatangan yang bersangkutan secara sementara karena alasan tertentu.

\section{Hasil Simulasi dari promodel 6.0}

Setelah simulasi dijalankan, maka akan kita dapatkan hasilnya. Adapun berikut ini adalah penjelasan dari hasil yang ada :

a. Location, yang terdiri dari :

1. Scheduled Time : jumlah waktu yang didjawalkan untuk melakukan pekerjaannya

2. Capacity: kapasitas dari tiap lokasi yang ada

3. Total Entities: banyaknya $125 y$ stem yang masuk ke dalam loket selama jam kerja berlangsung.

4. Average Time Per Entry: Waktu rata-rata setiap kedatangan dilokasi.

5. Average Contents : Bobot waktu rata-rata kedatangan nasabah yang berada dilokasi.

6. Maximum Contents : Jumlah maksimum nasabah yang berada dilokasi.
7. Current Contents : Jumlah nasabah yang berada dilokasi ketika simulasi berakhir.

8. Utilization : persen utilisasi dari lokasi.

\section{b. Location state Single}

1. Percent Empty : Persentasi waktu dimana tidak terdapat entity

2. Percent Part Occupied : Persentase waktu dari lokasi ketika memiliki 125ystem tapi tidak dengan kapasitas.

3. Percent Full : Persentasi dimana kapasitas dari lokasi tersebut terisi penuh.

4. Percent Down : Persentasi waktu yang menurun sebagai hasil yang tidak terjadwal.

\section{c. Location State Single}

1. Percent Operation: Persentasi dimana loket melayani/ melakukan prosesnya.

2. Percent Setup : persentasi waktu yang dibutuhkan oleh sistem untuk melakukan setup.

3. Percent Idle : Persentasi dimana tidak terdapat nasabah dalam lokasi.

4. Percent Waiting : persentasi lokasi menunggu untuk resource.

d. Failed Arrival : banyaknya nasabah yang gagal dilayanai oleh suatu loket karena terbatasnya kapasitas.

\section{e. Resources}

1. Scheduled Time : Jumlah jam yang dijadwalkan bagi lokasi untuk tersedia.

2. Time Used : Waktu yang digunakan resource untuk melakukan proses pada entiti.

3. Average Time Per Use : Waktu ratarata resousrces untuk melakukan proses pada entiti.

4. Total Time in Operation : Total waktu yang digunakan resource untuk melakukan proses.

5. Total Time Waiting : Total waktu resource untuk menunggu resource lain. 
6. Total Time Blocked : Total waktu resource untuk menunggu lokasi tujuan memiliki kapasitas yang tersedia.

7. Total Time Moving : Total waktu resource untuk bergerak ke lokasi.

\section{f. Resource state}

1. Percent in Use : Persentase waktu resources melakukan proses.

2. Percent idle: Persentase menunggu dari resource.

g. Entity activity

1. Total Exits : jumlah entiti yang keluar dari sistem pelayanan

2. Current Quantity In System : jumlah entiti yang masih ada didalam sistem setelah simulasi berakhir.

3. Average Time In System : Waktu yang dihabiskan nasabah dalam sistem.

4. Average Time In Move Logic : Waktu rata-rata dari entiti saat berpindah antar lokasi.

5. Average Time In operation : waktu rata-rata proses selama diproses dilokasi.

6. Average Time Blocked : Waktu ratarata suatu entity menunggu untuk lokasi tujuannya memiliki kapasitas yang tersedia.

\section{h. Entity States}

1. Percent in operation: Persentase entiti menghabiskan waktu dalam proses dilokasi.

2. Percent waiting : Persentase entiti menunggu untuk resource.

3. Percent Blocked : Persentase entiti menunggu untuk lokasi selanjutnya tersedia.

4. Percent in Move : Persentase entiti bergerak antar lokasi.

\section{HASIL DAN PEMBAHASAN}

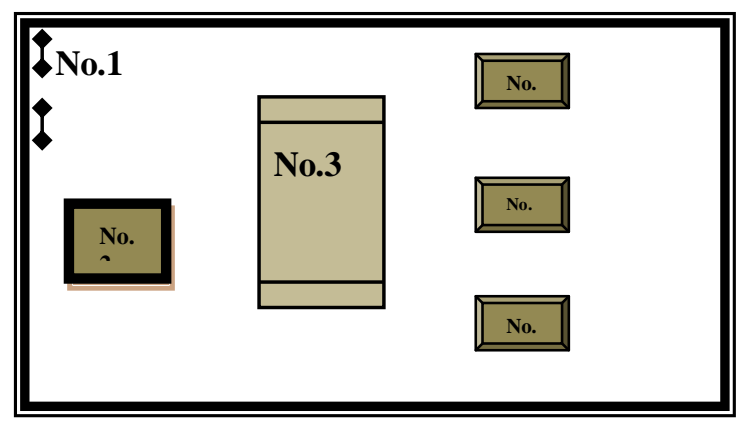

Gambar 7. Layout Simulasi

Keterangan :

$>1$ : Pintu masuk dan Pintu keluar

$>2$ : Daftar Nomor Antrian e-KTP

$>3$ : Bangku Antrian

$>4$ : Meja loket pembuatan e-KTP

Berikut adalah diagram alir pergerakan entitas dalam sistem :

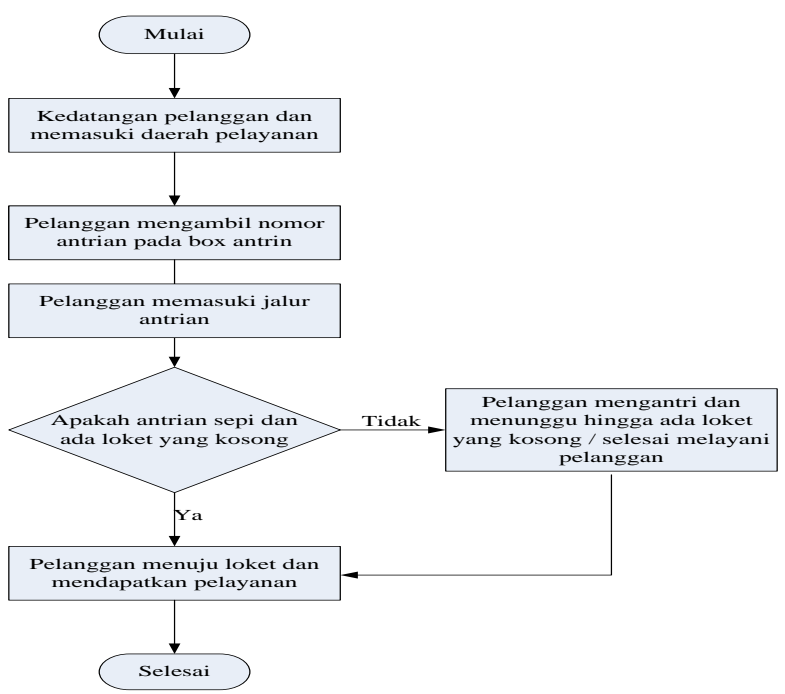

Gambar 8. Diagram alir pergerakan entitas dalam system

Sumber: (Kaikay,2009) 


\section{Hasil Output Simulasi Dengan Promodel}

Tabel 1.Hasil Output Location

\begin{tabular}{|l|c|r|}
\hline \multicolumn{1}{|c|}{ Name } & $\begin{array}{c}\text { Scheduled } \\
\text { Time (hr) }\end{array}$ & Utilization \\
\hline Pintu masuk keluar & 8 & 0,53 \\
\hline jalur ke tempat pendaftaran & 8 & 28,08 \\
\hline tempat pendaftaran & 8 & 0,24 \\
\hline jalur tunggu & 8 & 51,14 \\
\hline ruang tunggu & 8 & 3,34 \\
\hline loket 1 & 8 & 66,55 \\
\hline loket 2 & 8 & 57,24 \\
\hline loket 3 & 8 & 63,86 \\
\hline jalur loket 1 & 8 & 36,32 \\
\hline jalur loket 2 & 8 & 22,69 \\
\hline jalur loket 3 & 8 & 25,53 \\
\hline
\end{tabular}

\section{Tabel 2. Hasil Output Failed Arrivals}

\begin{tabular}{|l|l|r|}
\hline Entity Name & Location Name & Total Failed \\
\hline penduduk 1 & pintu masuk keluar & \\
penduduk 1 & jalur ke tempat pendaftaraan & 0,00 \\
penduduk 1 & tempat pendaftraan & 36,00 \\
penduduk 1 & jalur ke ruang tunggu & 0,00 \\
penduduk 1 & ruang tunggu & 481,00 \\
penduduk 1 & jalur ke loket 1 & 0,00 \\
penduduk 2 & pintu masuk keluar & 173,00 \\
penduduk 2 & jalur ke tempat pendaftaraan & 0,00 \\
penduduk 2 & tempat pendaftraan & 481,00 \\
penduduk 2 & jalur ke ruang tunggu & 0,00 \\
penduduk 2 & ruang tunggu & 481,00 \\
penduduk 2 & loket 2 & 0,00 \\
penduduk 2 & jarur ke loket 2 & 0,00 \\
penduduk 3 & pintu masuk keluar & 481,00 \\
penduduk 3 & jalur ke tempat pendaftaraan & 0,00 \\
penduduk 3 & tempat pendaftraan & 481,00 \\
penduduk 3 & jalur ke ruang tunggu & 0,00 \\
penduduk 3 & ruang tunggu & 481,00 \\
penduduk 3 & loket 3 & 0,00 \\
penduduk 3 & jalur ke loket 3 & 0,00 \\
\hline & & 481,00 \\
\hline
\end{tabular}

Tabel 3. Output Entity Activity

\begin{tabular}{|l|c|c|}
\hline Entity & $\begin{array}{c}\text { Waktu dalam } \\
\text { system (menit) }\end{array}$ & $\begin{array}{c}\text { Waktu menunggu } \\
\text { dalam antrian } \\
\text { (menit) }\end{array}$ \\
\hline Penduduk 1 & 71.00 & 15.30 \\
\hline Penduduk 2 & 43.00 & 10.98 \\
\hline Penduduk 3 & 56.00 & 11.87 \\
\hline Rata-rata & - & 12.71 \\
\hline
\end{tabular}

Tujuan dari pengolahan data dan pembuatan simulasi adalah untuk mengetahui tingkat utilitas dari setiap fasiitas pelayanan, waktu keseluruhan dalam sistem, dan waktu menunggu dalam antrian yang dialami oleh pelanggan.Setelah kita memperoleh hasilnya dari simulasi, maka selanjutnya kita analisis hasilnya untuk mengetahui sistem mana yang memerlukan perbaikan.

Dari hasil simulasi kita peroleh data seperti jumlah penduduk yang dilayani, tingkat utilitas, waktu keseluruhan dalam sistem dan waktu menunggu dalam antrian.

Dengan demikian hasil yang didapat dari simulasi dapat dilihat bahwa ditemukan kendala-kendala pada masing-masing lokasi.Terdapat tiga lokasi yang kurang memenuhi harapan penduduk yaitu pada pintu keluar masuk, tempat pendaftaran, dan ruang tunggu yang nilainya kurang dari 5\% saja sehingga tingkat utilitasnya tergolong rendah.Hal ini dikarenakan terjadinya penumpukan penduduk yang tidak bisa dikendalikan lagi akibatnya pintu masuk keluar membuat penduduk saling berdesak-desakkan. Oleh karena itu proses ini dinilai kurang efektif dan jauh dari harapan penduduk sehingga tingkat pelayanan terhadap kelurahan menjadi semakin buruk. Selanjutnya pada jalur tempat pendaftaran memperoleh $28.08 \%$, jalur loket 2 memperoleh 22,69\%, jalur loket 3 memperoleh $25,49 \%$, jalur loket 1 memperoleh $36,32 \%$, loket 1 memperoleh $66,55 \%$, loket 2 memperoleh $57,24 \%$, loket 3 memperoleh $63,86 \%$ dan tingkat utilitas jalur ke ruang tunggu memperoleh nilai $51.14 \%$. Hasil Output entity Activity yang didapat dari simulasi di atas dapat dilihat bahwa terdapat masalah pada bagian loket karena waktu menunggu antrian untuk satu orang lebih dari 12,71 menit, hal ini membuat antrian semakin panjang dan system ini dirasa kurang efektif dan mengalami gangguan yang cukup signifikan. Oleh karena itu harus mengadakan analisis lebih lanjut untuk mendapatkan system yang efektif dari sebelumnya sehingga tingkat pelayanan 
dapat ditingkatkan sehingga tidak terjadi kembali antrian yang panjang dan menghabiskan waktu.

Hasil simulasi antrian pada loket pembuatan e-KTP tersebut memiliki tingkat utilitas yang rendah yaitu belum optimalnya penggunaan stasiun tersebut dalam melakukan pelayanan pada penduduk dan adanya masalah-masalah teknis pada tiap-tiap lokasi seperti kekurangan loket antriantidak sebanding dengan kapasiatas penduduk yang datang, lamanya waktu pelayanan, kapasitas loket yang terbatas sehingga sistem antrian loket ini sangat perlu dianalisa lebih lanjut untuk melakukan perbaikan.

Oleh karena itu perlu adanya evaluasi ulang terhadap proses antrian di setiap lokasi sehingga utilitasnya meningkat dan tingkat pelayanan terhadap penduduk dapat dirasakan semaksimal mungkin sesuai visi dan misi kelurahan tersebut.

\section{SIMPULAN}

Hasil penelitian dilakukan dengan pola kedatangan penduduk berdistribusi poisson sedangkan waktu pelayanan berdistribusi eksponensial. Sistem antrian yang diawali ketika penduduk yang datang melalui pintu masuk menuju tempat pendaftaran nomor urut antrian, menunggu sampai nomor antrian dipanggil oleh petugas dan proses pembuatan e-KTP pun diproses, kemudian selesai, dengan begitu artinya penduduk keluar dari sistem ketika proses pembuatan e-KTP berakhir, pada loket pembuatan KTP elektonik ditempatkan 3 loket dengan sistem peraturan yang datang pertama kali akan dilayani terlebih dahulu, jumlah pengantri dalam sistem dan antrian serta sumber kedatangan penduduk tidak terbatas, jadi sistem antrian pada loket pembuatan e-KTP Kelurahan Kebon Pala Makassar mengikuti model antrian (M/M 11) : $(\mathrm{GD} / \infty / \infty)$. Performansi kerja dari sistem pelayanan pada loket pembuatan eKTP Kelurahan Kebon Pala Makassar meliputi tingkat utilitas server, jumlah pelanggan yang dilayani dan waktu menunggu penduduk dalam antrian untuk berbagai kondisi adalah sebagai berikut :

Tabel 4. Tingkat Utilitas

\begin{tabular}{lc}
\hline \multicolumn{1}{c}{ Name } & Tingkat Utilitas ( \% ) \\
\hline Pintu Masuk-Keluar & 0.53 \\
Jalur ke tempat pendaftaran & 28.03 \\
Tempat pendaftaran & 0.24 \\
Jalur ke ruang tunggu & 51.06 \\
Ruang Tunggu & 3.53 \\
Loket 1 & 62.31 \\
Loket 2 & 58.42 \\
Loket 3 & 60.85 \\
Jalur loket 1 & 35.87 \\
Jalur loket 2 & 22.63 \\
Jalur loket 3 & 25.49 \\
\hline
\end{tabular}

Hasil analisis data menggunakan promodel diatas dengan berbagai kondisi yang ada, maka dapat disimpulkan bahwa banyak permasalahan yang signifikan terhadap sistem antrian pada pembuatan e-KTP Kelurahan Kebon Pala Makassar dimana terdapat waktu antrian yang cukup lama dan juga tingkat utilitas server yang rendah sehingga tingkat pelayanan dinilai kurang memuaskan dan memiliki batas pengendalian yang kurang baik.

Sesuai analisis yang didapat maka sistem antrian dapat dikatakan dalam kondisi buruk, dengan tingkat utilitas hampir tidak mencapai $50 \%$ sehingga usulan atas perbaikan sistem tersebut dirasa sangat diperuntukkan bagi Kelurahan Kebon Pala, hal ini merupakan pembelajaran untuk kelurahan agar terus meningkatkan kualitas pelayanan yang lebih memadai supaya penduduk merasa puas terhadap fasilitas pelayanan yang diberikan dan dapat meminimalisir waktu mengantri.

\section{DAFTAR PUSTAKA}

[1] Harrel, Charles, Biman, K Ghosh, Royce O. Bowden Jr., Simulation Using Promodel. (Third Edition). New York : Mc. Graw Hill. 2012. 
[2] Sugiyono. Metode Penelitian Kuantitatif, Kualitatif, dan $R \& D$. Bandung: Alfabeta. 2009.

[3] Suparti dan Wulandari, Jurnal Teknik. Analisis Antrian Service Motor di Dealer Resmi Yamaha Kondang Simo dengan Simulasi Arena ,Jurnal Teknik Industri dan Informasi. 3 (1). 2014.

[4] Tannady, et.al, Analisis Studi Gerakan dan Simulasi Antrian. Jurnal Ilmiah Teknik Industri.2 : 109-114. 2014

[5] Mungin, Parwadi, Winnie Septiani. A Discreate-Event Simulation Methodology to Optimize the Number of Beds In Hospital, Proceedings of the World Congress on Engneering And Computer Science. 2. 2014.

[6] http://www.google.co.id/amp/s/paimin 92.wordpress.com/2014/11/30/materipromodel (Diakses 30/11/2018)

[7] https://thesis.binus.ac.id/doc/Bab2/200 8-1-00470-TISI.pdf (Diakses $30 / 11 / 18)$

[8] Kakiay,Thomas J. Pengantar Sistem Simulasi. Yogyakarta: Andi. 2004. 